\title{
Anticancer and antimicrobial potential of enterocin 12a from Enterococcus faecium
}

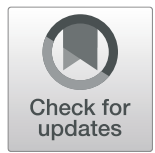

\author{
Preeti Sharma', Sumanpreet Kaur ${ }^{1}$, Bhupinder Singh Chadha', Raminderjit Kaur ${ }^{2}$, Manpreet Kaur ${ }^{3}$ and \\ Sukhraj Kaur ${ }^{1 *}$
}

\begin{abstract}
Background: Increase in the number of infections caused by Gram-negative bacteria in neutropenic cancer patients has prompted the search for novel therapeutic agents having dual anticancer and antimicrobial properties. Bacteriocins are cationic proteins of prokaryotic origin that have emerged as one of the most promising alternative antimicrobial agents with applications as food preservatives and therapeutic agents. Apart from their antimicrobial activities, bacteriocins are also being explored for their anticancer potential.
\end{abstract}

Results: In this study, a broad-spectrum, cell membrane-permeabilizing enterocin with a molecular weight of 65 kDa was purified and characterized from the culture supernatant of vaginal Enterococcus faecium 12a. Enterocin 12a inhibited multidrug-resistant strains of various Gram-negative pathogens such as Salmonella enterica, Shigella flexneri, Vibrio cholerae, Escherichia coli and Gram-positive, Listeria monocytogenes, but had no activities against different strains of gut lactobacilli. The mass spectrometric analysis showed that the enterocin 12a shared partial homology with $4 \mathrm{Fe}-4 \mathrm{~S}$ domain-containing redox protein of E. faecalis R712. Further, enterocin 12a selectively inhibited the proliferation of various human cancer cell lines in a dose-dependent manner but not that of normal human peripheral blood mononuclear cells. Enterocin 12a-treated cancer cells showed apoptosis-like morphological changes.

Conclusion: Enterocin 12a is a novel bacteriocin that has anticancer properties against human cell lines and negligible activity towards non-malignant cells. Therefore, it should be further evaluated for its anticancer potential in animal models.

Keywords: Bacteriocin, Enterocin, Enterococcus faecium, Anticancer, Commensal, Antimicrobial

\section{Background}

Cancer is the second most prevalent cause of death worldwide that accounted for 9.6 million deaths, and 18.1 million new cases in 2018 [1]. Conventional cancer chemotherapeutic agents are mostly non-selective to cancer cells that result in serious side-effects such as organ toxicity, immunosuppression, and also contribute to the development of drug resistance in cancer cells. Immunosuppression due to anticancer drug regimen

\footnotetext{
*Correspondence: drsukhrajkaur@gmail.com

'Department of Microbiology, Guru Nanak Dev University, Amritsar, Punjab 143005, India

Full list of author information is available at the end of the article
}

and breakdown in the mucosal barrier due to the use of invasive devices in cancer patients make them susceptible to bacterial infections that require long-term prophylactic antibiotic regimens [2]. Further, the effectiveness of antibiotic regimen to treat infections in cancer patients is compromised due to the emergence of drugresistant Gram-negative bacterial pathogens that predominates in neutropenic patients [3]. Therefore, novel anticancer agents that specifically inhibit cancer cells and have dual anticancer and antimicrobial activities are expected to act as prophylaxis against bacterial infections along with inhibiting the growth of tumors in cancer patients [4].

(C) The Author(s). 2021 Open Access This article is licensed under a Creative Commons Attribution 4.0 International License, which permits use, sharing, adaptation, distribution and reproduction in any medium or format, as long as you give appropriate credit to the original author(s) and the source, provide a link to the Creative Commons licence, and indicate if changes were made. The images or other third party material in this article are included in the article's Creative Commons licence, unless indicated otherwise in a credit line to the material. If material is not included in the article's Creative Commons licence and your intended use is not permitted by statutory regulation or exceeds the permitted use, you will need to obtain permission directly from the copyright holder. To view a copy of this licence, visit http://creativecommons.org/licenses/by/4.0/. The Creative Commons Public Domain Dedication waiver (http://creativecommons.org/publicdomain/zero/1.0/) applies to the data made available in this article, unless otherwise stated in a credit line to the data. 
Exploration for novel antimicrobials to treat bacterial infections has led to renewed interest in the search for bacteriocins [5]. Bacteriocins are cationic proteins secreted by bacteria that kill the target bacteria mainly by forming pores in their cell membrane or in some cases by inhibiting protein synthesis and DNA replication [6]. Bacteriocins derived from lactic acid bacteria (LAB) have GRAS (Generally regarded as safe) status and therefore they are considered safe. Two such bacteriocins, nisin and pediocin have been approved by the Food and Drug Administration (FDA) for use as food preservatives [7]. Bacteriocins are also being considered as potential new generation therapeutic agents that can be employed as stand-alone drugs [6] or as adjuncts to conventional antibiotics $[8,9]$. In healthcare studies, nisin was shown to successfully treat mastitis in humans [10] and cows [11].

Along with the antimicrobial activities, a few bacteriocins of LAB origin such as nisin [12], pediocin, and plantaricin have demonstrated anti-proliferative effects against human cancer cell lines, in in vitro and mice experiments [13]. This indicates their potential for use as both antimicrobial and anticancer agents. However, bacteriocins purified from LAB generally have narrowspectrum antimicrobial activities as they are known to inhibit Gram-positive bacteria only [5, 14]. Therefore, bacteriocins that inhibit Gram-negative pathogens along with Gram-positive are expected to have wider applications. Thus, this study was focused on studying the anticancer potential of a broad-spectrum enterocin purified from the culture supernatant (CS) of E. faecium 12a. Further, the mode of anticancer activity and toxicity of the enterocin was also studied.

\section{Results}

Cumulative production kinetics of the antimicrobial substance in the CS

Before the purification of enterocin 12a, its production kinetics was studied in De Man Rogosa and Sharpe medium (MRS) broth. As shown in Fig. 1, enterocin 12a appeared in the CS $4 \mathrm{~h}$ after the inoculation of $E$. faecium 12a in MRS broth. The concentration of $12 \mathrm{a}$ peaked (640 arbitrary units per $\mathrm{ml}, \mathrm{AU} / \mathrm{ml})$ at $8 \mathrm{~h}$ after which it plateaued till $20 \mathrm{~h}$. After $20 \mathrm{~h}$, there was a $50 \%$ decrease in the antimicrobial activity of the CS. The production of the antimicrobial substance was growthassociated as it peaked in the early log phase and plateaued in the stationary phase.

\section{Purification and identification of enterocin 12a}

For the purification of antimicrobial compound from the CS, ammonium sulfate precipitation, cation-exchange chromatography and reverse-phase high-performance liquid chromatography (RP-HPLC) was carried out. Purified enterocin fraction yielded a single peak on the chromatogram at the retention time of $1.72 \mathrm{~min}$ (Fig. 2a). After RP-HPLC, a 10.11 fold increase in the specific activity of enterocin was observed and the final yield percentage was 1.6 (Table 1). SDS-PAGE analysis of the purified fraction showed a single band with a molecular weight of 65 kDa (Fig. 2b; Supplementary Fig. 1, Supplementary Fig. 2). Further, to test the antimicrobial activity of the $65 \mathrm{kDa}$ band, gel overlay assay was performed against Salmonella enterica as the indicator pathogen, and a clear zone corresponding to the band was obtained (Fig. 2b; Supplementary Fig. 3). The band was cut

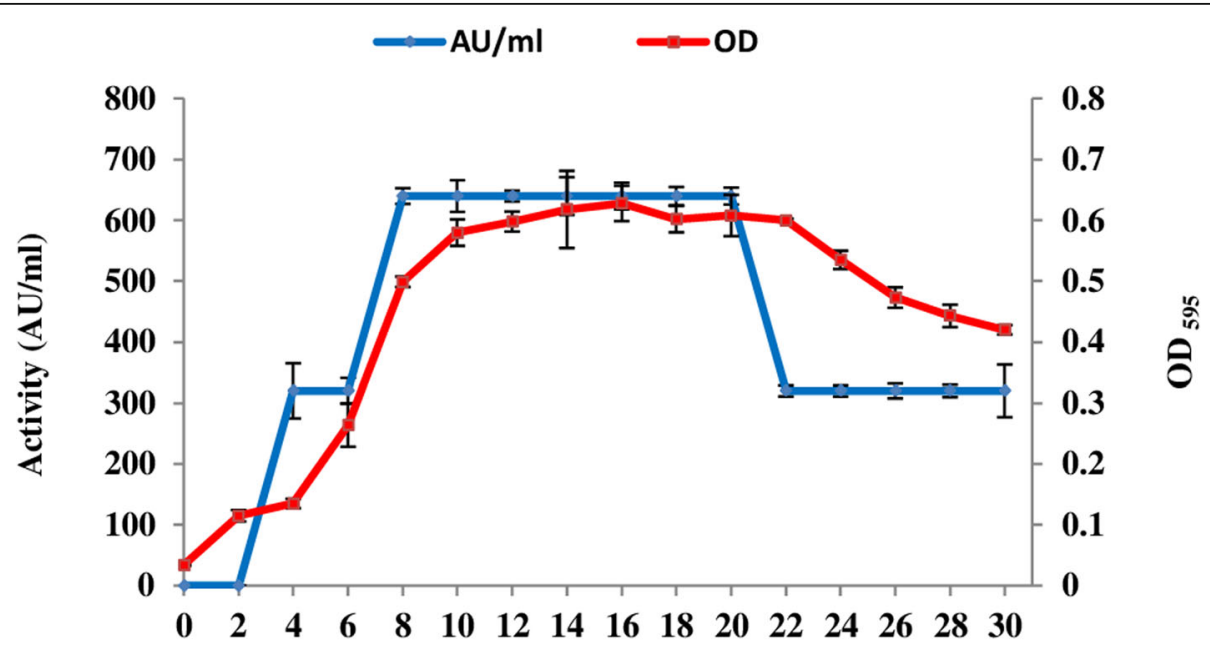

Time (h)

Fig. 1 Kinetics of enterocin production and growth kinetics of E. faecium 12a. The antimicrobial activity of CS was measured by using agar gel diffusion method against S. enterica, whereas, the growth of E. faecium in MRS media was measured by measuring absorbance at $595 \mathrm{~nm}$ after every $2 \mathrm{~h}$. Error bars are representative of the three independent experiments performed in triplicates 

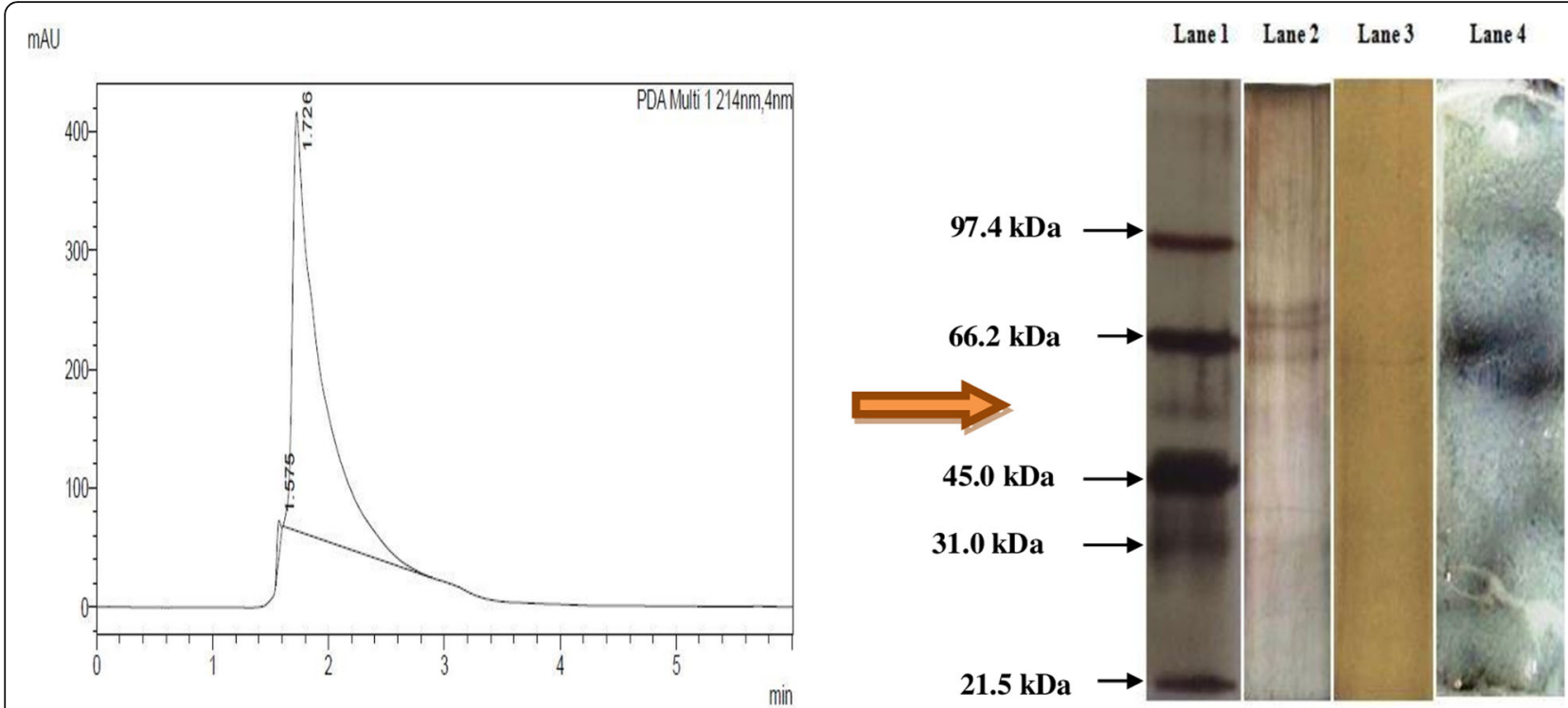

Retention time (min)

(a)

\section{Protein sequence coverage: $\mathbf{4 8} \%$}

Matched peptides shown in bold red.

1 MYFSLILPLF LVDILGQGSP YFCRLICPIG MLEGGLPLVL LNRSMRSTIG

51 FLYYWKGIIL IVTLLLSIII YRPFCKYICP LRAIYSIFNP ISIFRYRLDK

101 DKCTNCGKCK KVCQMNKDSV ENCNHLECIR CGRCKNACPV DAISYGVRR

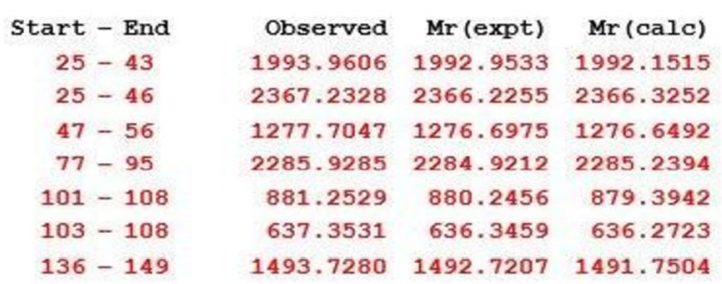

(c)

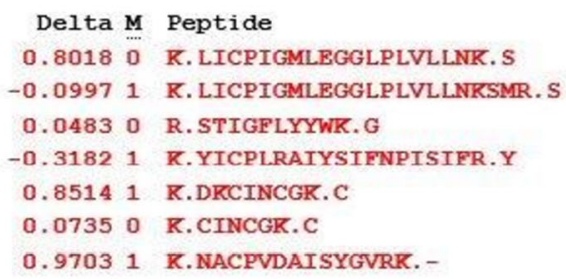

(b)

\footnotetext{
Fig. 2 (a) U-HPLC chromatogram of the purified enterocin 12a (b) SDS-PAGE of purified enterocin 12a and gel overlay with S. enterica. Lane 1: molecular weight marker. Lane 2: partially-purified enterocin 12a after cation exchange chromatography. Lane 3: purified enterocin 12a after RPHPLC. Lane 4: Zone of inhibition against S. enterica observed in the agar gel overlay assay corresponding to the position of the band on the SDSPAGE of enterocin 12a (c) Peptide mass fingerprinting (PMF) analysis of enterocin 12a. The PMF followed by MASCOT search in NCBlprot shows the matched amino acid residues (in red bold) of the seven peptide fragments with the 4Fe-4S domain-containing protein of E. faecalis R712
}

and subjected to MALDI TOF/TOF MS/MS analysis. Protein identification by MASCOT search in NCBIprot showed that the peptide fragments of enterocin 12a shared similarity with $48 \%$ of $4 \mathrm{Fe}-4 \mathrm{~S}$ domain-containing protein of E. faecalis R712 with significant $(p<0.05)$ coverage score of 121(Fig. 2c). The seven peptides that matched the $4 \mathrm{Fe}-4 \mathrm{~S}$ domain-containing protein of E. faecalis $\mathrm{R} 712$ are listed in Fig. 2c. 
Table 1 Steps of purification and percent yield of enterocin 12a purified from E. faecium 12a

\begin{tabular}{|c|c|c|c|c|c|c|c|}
\hline Purification step & $\begin{array}{l}\text { Total volume } \\
(\mathrm{ml})\end{array}$ & $\begin{array}{l}\text { Activity } \\
\text { (AU/ } \\
\mathrm{ml} \text { ) }\end{array}$ & $\begin{array}{l}\text { Total } \\
\text { activity }^{a}\end{array}$ & $\begin{array}{l}\text { Total } \\
\text { Protein } \\
\text { (mg) }\end{array}$ & $\begin{array}{l}\text { Specific } \\
\text { activity }^{b}\end{array}$ & $\begin{array}{l}\text { Fold-Increase in the specific } \\
\text { activity }\end{array}$ & $\begin{array}{l}\text { Percent } \\
\text { Yield }\end{array}$ \\
\hline CS & 1000 & 68,266 & $6.8 \times 10^{7}$ & 625 & 108,800 & 1 & 100 \\
\hline Ammonium sulphate ppt. & 200 & 136,528 & $2.7 \times 10^{7}$ & 215 & 125,581 & 1.15 & 39.7 \\
\hline Cation-exchange fraction & 30 & 273,056 & $8.1 \times 10^{6}$ & 33 & 245,455 & 2.26 & 11.9 \\
\hline $\begin{array}{l}\text { Reverse-phase } \\
\text { chromatography }\end{array}$ & 2 & 546,112 & $1.1 \times 10^{6}$ & 1 & $\begin{array}{l}1,100 \\
000\end{array}$ & 10.11 & 1.6 \\
\hline
\end{tabular}

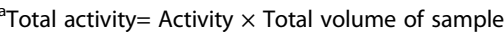

${ }^{\mathrm{b}}$ Specific activity $=$ Total activity/ Total protein

The antimicrobial activities of both CS and purified enterocin 12a were determined against various pathogens and commensal lactobacilli strains. Results showed that both crude and purified enterocin 12a inhibited Gram-negative pathogenic strains such as $S$. enterica, Shigella flexneri, Escherichia coli, and Vibrio cholerae but did not inhibit Gram-positive bacteria such as Staphylococcus aureus, Streptococcus pyogenes, and lactobacilli spp., except Listeria monocytogenes. Further, CS also inhibited Mycobacterium smegmatis but purified enterocin 12 a had no activity against $M$. smegmatis (Table 2).

The zone of inhibition $(\mathrm{mm})$ of CS and enterocin 12a against indicator bacterial strains was determined by using agar gel diffusion assay. The results are the mean \pm

Table 2 Antimicrobial activity of the CS and enterocin 12a against various indicator bacterial strains

\begin{tabular}{lll}
\hline Indicator bacteria & \multicolumn{2}{l}{ Zone of inhibition (mm) } \\
\cline { 2 - 3 } & CS & Enterocin 12a \\
\hline S. enterica MTCC 733 & $16 \pm 0.1$ & $15 \pm 0.1$ \\
EsC. coli MTCC 119 & $13 \pm 0.2$ & $13 \pm 0.2$ \\
Sh. flexneri MTCC 1457 & $15 \pm 0.2$ & $15 \pm 0.2$ \\
List. monocytogenes MTCC 657 & $14 \pm 0.3$ & $13 \pm 0.3$ \\
V. cholerae MTCC3906 & $13 \pm 0.3$ & $12 \pm 0.3$ \\
M. smegmatis MTCC6 & $14 \pm 0.2$ & - -* \\
St. pyogenes MTCC 1927 & - & - \\
Staph. aureus MTCC 96 & - & - \\
Pseudomonas aeruginosa MTCC 741 & - & - \\
Lactobacillus plantarum L12 & - & - \\
L. plantarum L14 & & - \\
L. paracasei L32 & - & - \\
L. pentosus S45 & - & - \\
L. fermentum L13 & - & - \\
L. fermentum L18 & - & - \\
L. casei S49 & - & - \\
\hline
\end{tabular}

*-No zone of inhibition observed standard deviation (SD) of three independent experiments performed in triplicates.

Physico-chemical characteristics of purified enterocin 12a The thermostability of purified enterocin $12 \mathrm{a}$ was determined at different temperatures. As shown in Table 3, the antimicrobial activity of enterocin $12 \mathrm{a}$ remained stable at temperatures 60 and $80^{\circ} \mathrm{C}$; however, the enterocin was completely inactivated beyond 30 min exposure to a temperature of $100^{\circ} \mathrm{C}$. Further, the $\mathrm{pH}$ sensitivity of enterocin 12a was determined. Results showed that enterocin 12a remained active in the $\mathrm{pH}$ range $2-10$ and exhibited maximum activity at $\mathrm{pH} 4$ (Table 3 ). Further, the antimicrobial activity of enterocin $12 \mathrm{a}$ was stable to the action of various solvents such as methanol, chloroform, and acetonitrile (Table 3).

The effect of various enzymes on the stability of enterocin $12 \mathrm{a}$ was tested. It was observed that all three proteases resulted in complete abrogation of the antimicrobial activity of enterocin 12a, thereby showing its proteinaceous nature (Table 3 ). On the other hand, lipase treatment did not affect the antimicrobial activity of enterocin 12a (Table 3).

Zones of inhibitions $(\mathrm{mm})$ of enterocin 12a were measured by using agar gel diffusion assay against $S$. enterica. The results are the mean $\pm \mathrm{SD}$ of three independent experiments performed in triplicates.

\section{Effect of enterocin 12a on membrane permeability}

The effect of enterocin 12a on cell membrane permeability of $S$. enterica cells was determined by staining the cells with the fluorescent dye, propidium iodide (PI). Histograms (Fig. 3a) show that in the absence of enterocin $12 \mathrm{a}$, S. enterica cells exhibited $13.5 \%$ fluorescence. Whereas, in the presence of enterocin 12a, the fluorescence of S. enterica cells increased to 71.7 and $91.7 \%$ after 15 and $30 \mathrm{~min}$, respectively (Fig. 3b and c). Simultaneously, the confocal microscopy images (Fig. 4) of enterocin 12a-treated S. enterica cells stained with PI showed an exponential increase in the number of 
Table 3 Physico-chemical characterization of enterocin 12a

\begin{tabular}{|c|c|c|}
\hline Physico-chemical parameters & Treatments & Residual activity of enterocin $12 \mathrm{a}$ in terms of zone of inhibition ( $\mathrm{mm}$ ) \\
\hline & Untreated control & $15 \pm 0.11$ \\
\hline \multirow[t]{7}{*}{ Temperature } & $60^{\circ} \mathrm{C}(30 \mathrm{~min})$ & $15 \pm 0.12$ \\
\hline & $60^{\circ} \mathrm{C}(60 \mathrm{~min})$ & $15 \pm 0.20$ \\
\hline & $80^{\circ} \mathrm{C}(30 \mathrm{~min})$ & $14 \pm 0.20$ \\
\hline & $80^{\circ} \mathrm{C}(60 \mathrm{~min})$ & $13 \pm 0.11$ \\
\hline & $100^{\circ} \mathrm{C}(15 \mathrm{~min})$ & $8 \pm 0.15$ \\
\hline & $100^{\circ} \mathrm{C}(30 \mathrm{~min})$ & $*_{-}$ \\
\hline & $121^{\circ} \mathrm{C}(15 \mathrm{~min})$ & - \\
\hline \multirow[t]{5}{*}{$\mathrm{pH}$} & 2 & $13 \pm 0.14$ \\
\hline & 4 & $14 \pm 0.12$ \\
\hline & 6 & $13 \pm 0.15$ \\
\hline & 8 & $12 \pm 0.13$ \\
\hline & 10 & $11 \pm 0.12$ \\
\hline \multirow[t]{3}{*}{ Solvents $(50 \% v / v)$} & Chloroform & $14 \pm 0.11$ \\
\hline & Methanol & $15 \pm 0.11$ \\
\hline & Acetonitrile & $15 \pm 0.11$ \\
\hline \multirow[t]{4}{*}{ Enzymes (1 mg/ml) } & Proteinase $\mathrm{K}$ & - \\
\hline & Pepsin & - \\
\hline & Trypsin & - \\
\hline & Lipase & $15 \pm 0.12$ \\
\hline
\end{tabular}

*-No zone of inhibition observed

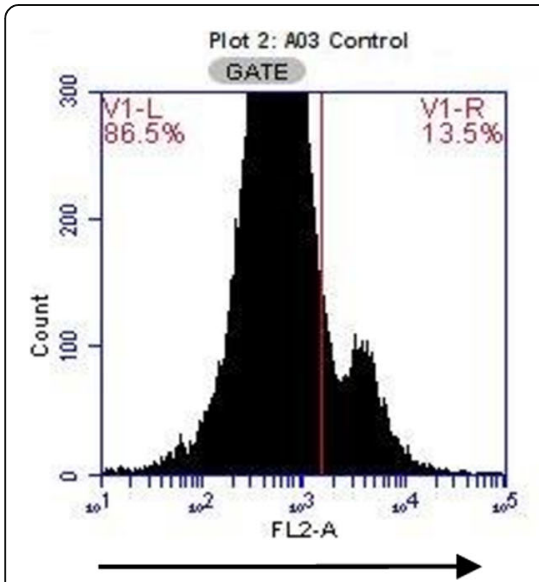

PI fluorescence

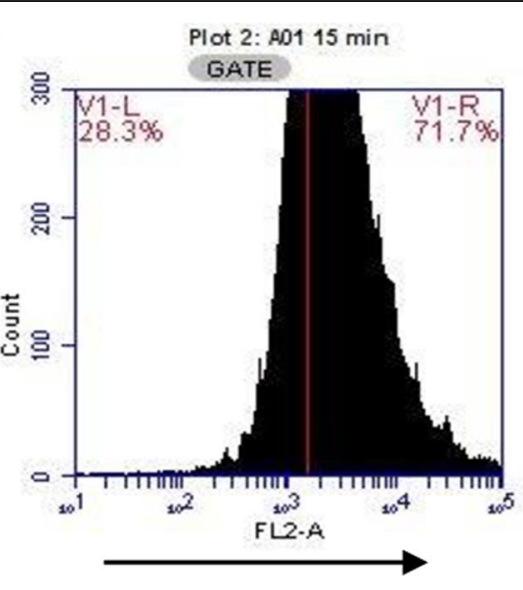

PI fluorescence

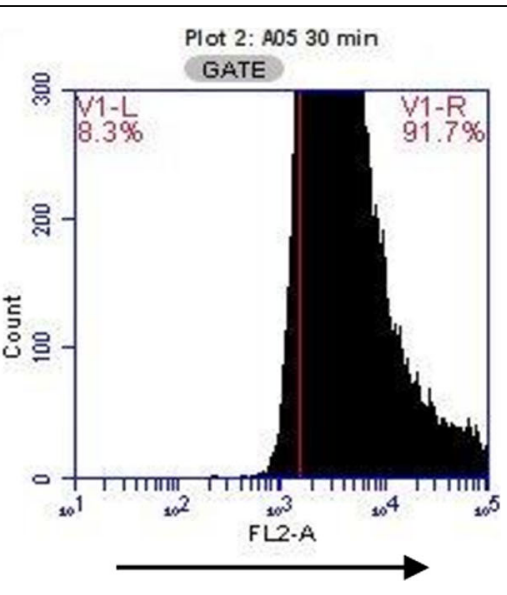

PI fluorescence

\section{a}

b

c

Fig. 3 Histograms depicting PI fluorescence of S. enterica cells a) untreated control b) enterocin 12a-treatment for 15 min c) enterocin 12 atreatment for $30 \mathrm{~min}$. The cells of $\mathrm{S}$. enterica were treated with $5 \mu \mathrm{g} / \mathrm{ml}$ of enterocin for 15 and $30 \mathrm{~min}$. The cells were washed by centrifugation and stained with PI. The fluorescence of the Pl-stained cells was determined by flow cytometer. Data are represented as histograms with counted bacterial events displayed on $y$-axis, and increase in fluorescence on the $x$-axis 


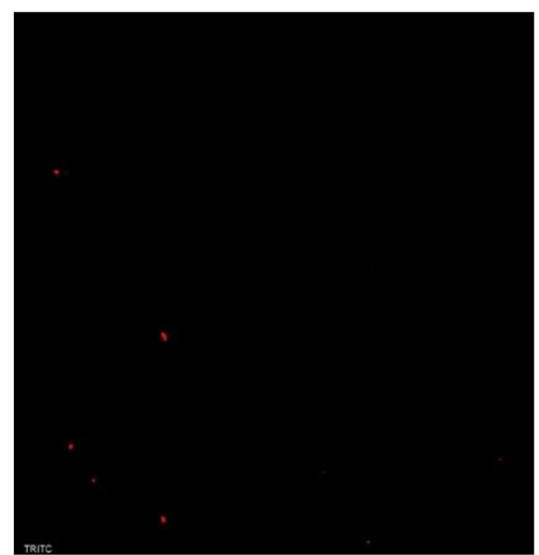

a

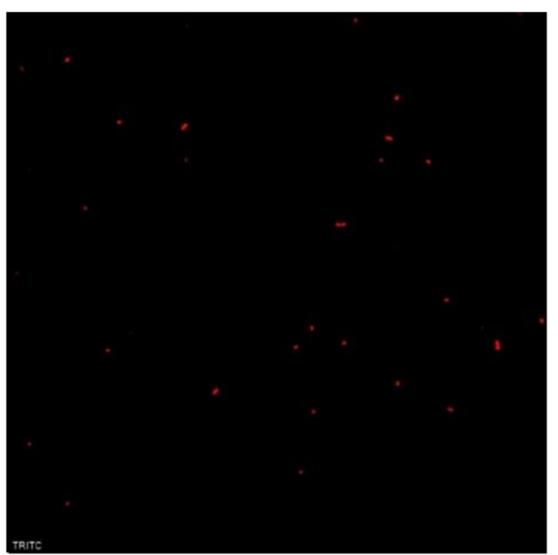

b

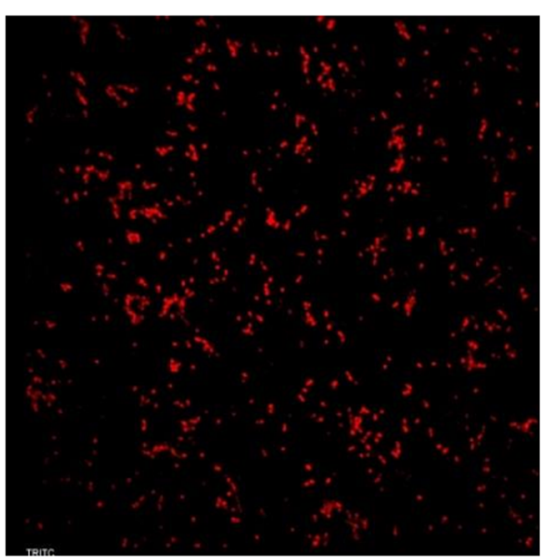

c

Fig. 4 Confocal microscopy (magnification $1000 \mathrm{X}$ ) images of Pl-stained S. enterica cells (a) without enterocin $12 \mathrm{a}$ treatment (b) with enterocin $12 \mathrm{a}(5 \mathrm{\mu g} / \mathrm{ml})$ treatment for $15 \mathrm{~min}$ (c) with enterocin $12 \mathrm{a}(5 \mu \mathrm{g} / \mathrm{ml})$ treatment for $30 \mathrm{~min}$

fluorescent cells with an increase in the treatment time as compared to the untreated cells (Fig. 4).

\section{Hemolytic activity of enterocin $12 a$}

The toxicity of enterocin 12a was determined by testing its hemolytic activity against human red blood cells (RBCs). Results (Fig. 5) showed that the treatment of RBCs with 2-fold dilutions of enterocin did not result in hemolysis. The percent RBC lysis observed after treatment with 10 and $5 \mu \mathrm{g} / \mathrm{ml}$ of enterocin was 4.5 and $2.5 \%$, respectively which was not significant $(p<0.0001)$ as compared to the untreated RBCs. On the other hand, treatment with $1 \%$ Triton X-100 resulted in complete RBC lysis (Fig. 5).

\section{Anti-proliferative activity of enterocin $12 \mathrm{a}$}

Evaluation of the antiproliferative activities of purified enterocin 12a on the cancer cell lines such as cervical cancer cell line, HeLa; colonic epithelial cell line, HCT15; lung cancer cell line, A549 and osteosarcoma cell line, MG-63 was done using MTT (3-4, 5dimethylthiazol-2-yl)-2, 5-diphenyltetrazolium) assay. Enterocin 12a inhibited the growth of all the cell lines in a dose-dependent manner (Fig. 6). At the highest dose of $5 \mu \mathrm{g} / \mathrm{ml}$, enterocin 12a reduced the viabilities of A549, HeLa, HCT-15, and MG-63 to 8.4, 24.1, 23.2 and 34.3\% respectively (Fig. 6). The $50 \%$ inhibitory concentration $\left(\mathrm{IC}_{50}\right)$ values of the enterocin 12a for A549, HeLa, HCT15, and MG-63 cell lines was calculated as 0.08, 1.54, 1.07 and $2.1 \mu \mathrm{g} / \mathrm{ml}$, respectively. The antiproliferative

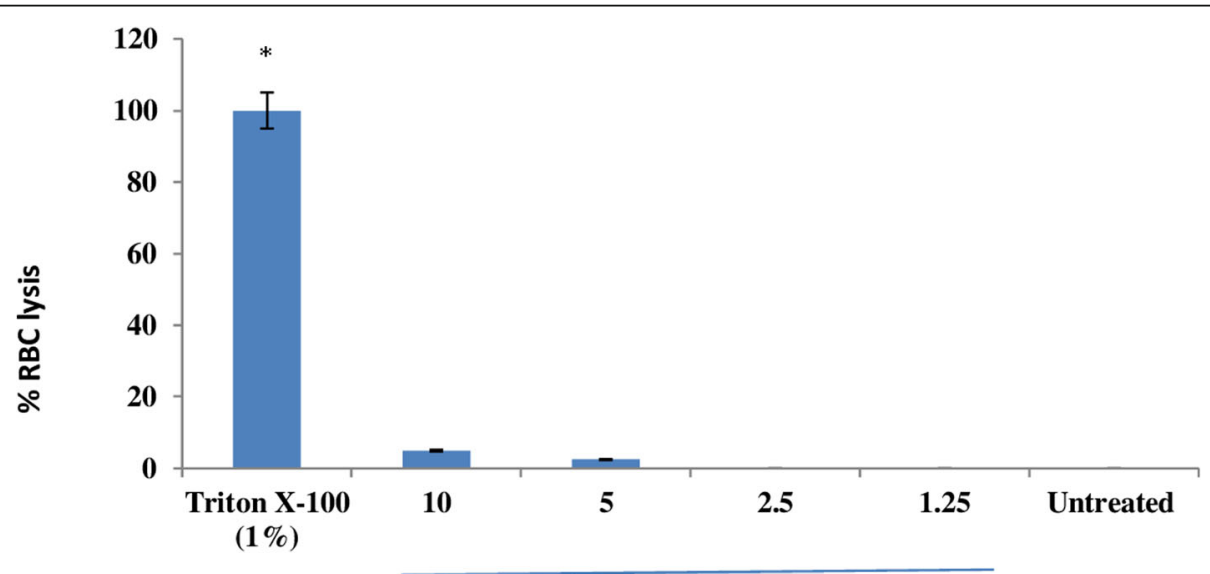

\section{Enterocin 12a $(\mu \mathrm{g} / \mathrm{ml})$}

Fig. 5 Hemolytic activity of enterocin 12a. Red blood cell samples suspended in PBS were treated with different concentrations of enterocin 12a for 1 h. Triton X-100 (1\%) was used as a positive control. Error bars are representative of SD of the three independent experiments performed in triplicates. *Significance $(P<0.0001)$ was calculated by comparing all the groups to the untreated control by using independent Student's $t$-test 


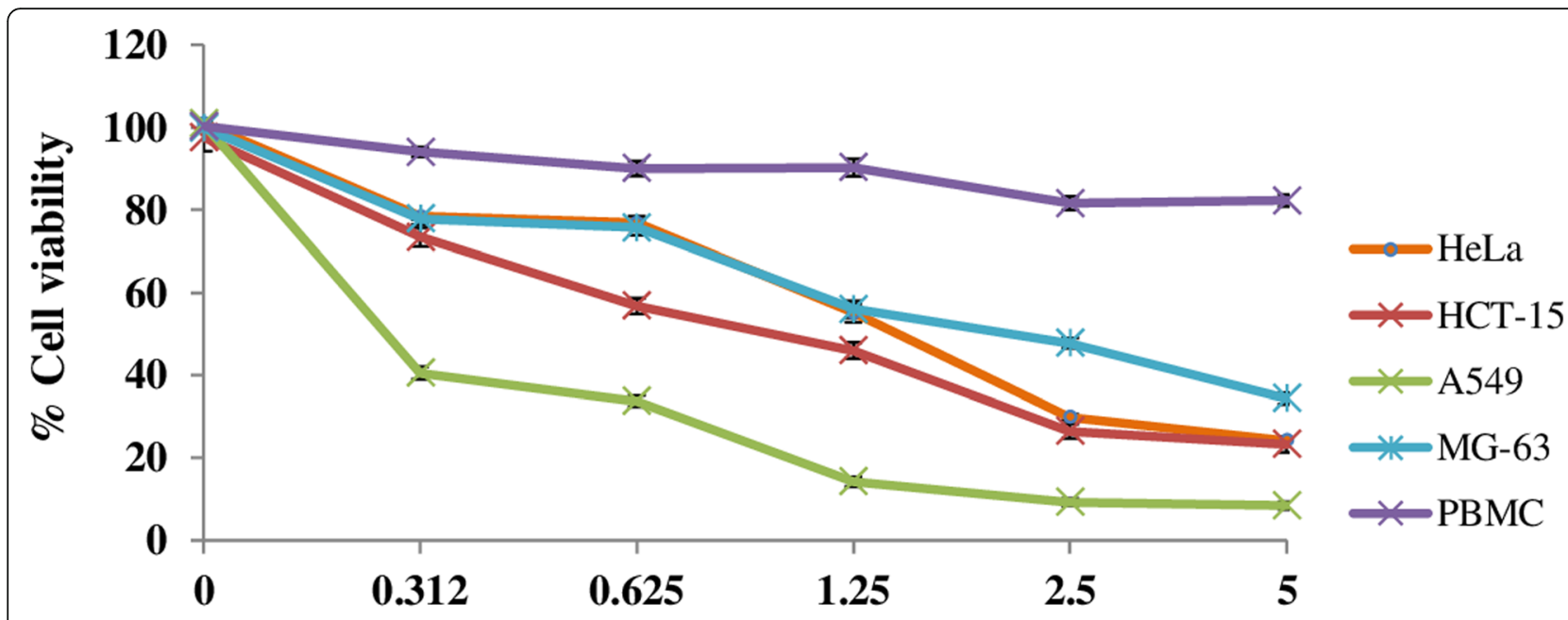

\section{Enterocin 12a $(\mu \mathrm{g} / \mathrm{ml})$}

Fig. 6 The anti-proliferative effects of different concentrations of enterocin 12a on the viabilities of cell lines A549, HeLa, HCT-15, MG-63 and PBMC as demonstrated by MTT assay. Error bars are representative of SD of the three independent experiments. *Significance (P < 0.0001$)$ was calculated by comparing all the groups to the untreated control by using independent Student's t-test

effect of enterocin 12a against normal human peripheral blood mononuclear cells (PBMCs) was also determined. The residual viability of PBMCs after treatment with enterocin $12 \mathrm{a}$ was $82.2 \%$ that was not significant $(p<$ 0.05) as compared to the untreated control (Fig. 6).

\section{Microscopic detection of morphological changes in the CS-treated cell lines}

Further, to study the mode of antiproliferative activity of enterocin 12a, morphological changes of enterocin 12atreated HCT-15 cells were studied by bright field and fluorescent microscopy. Most of the cells in the control untreated sample remained viable with normal cell morphology having a clear outline of the cell membrane and nucleus (Fig. $7 \mathrm{a}$ and c). On the other hand, cells treated with enterocin 12a showed morphological changes typical of apoptosis (Fig. 7b and d). Enterocin 12a-treated and Giemsa-stained cells (Fig. 7b) showed chromatin condensation and nuclear fragmentation. Similarly, cells stained with fluorescent dyes, PI and Hoechst 33342 (7D) showed cell shrinkage and nuclear fragmentation.

\section{Discussion}

Eighty percent of the patients with hematologic malignancies and $10-15 \%$ of the patients with solid tumors develop infections associated with neutropenia following more than one chemotherapy cycle [15]. Many studies have shown the benefits of using antimicrobials in conjunction with anticancer agents in reducing the mortality rate in cancer patients [3]. Thus, in this study, a novel enterocin 12a having selective anticancer activities against malignant cells was purified and characterized. $E$. faecium 12a was selected for the purification of enterocin as it possessed broad-spectrum antimicrobial activity, good probiotic properties, and did not harbor genes for known virulence factors as shown in our previous study [16]. Enterocin 12a was characterized as a novel high molecular weight protein that inhibited several Gramnegative pathogens but had no activities against Grampositive bacteria such as St. pyogenes, Staph. aureus and commensal lactobacilli, except $L$. monocytogenes. Among the already known enterocins of $E$. faecium, enterocin E-760 [17], T1 [18], enterocin A and B [19] were known to exhibit antimicrobial activities against Gram-negative bacteria; however, all of them had molecular weights of less than $10 \mathrm{kDa}$. Secondly, their antimicrobial spectrum differed from enterocin 12a, as they all inhibited Staph. aureus. Enterocins A and B also inhibited several strains of lactobacilli. Other enterocins of E. faecium such as AS48 and enterocin P [20] inhibited Gram-positive bacteria only. AS48 was shown to inhibit Gram-negative bacteria only in combination with treatments that disrupted the outer membrane of Gram-negative bacteria such as the use of EDTA, tripolyphosphate, polymyxin $\mathrm{B}$, or pulsed electric fields [21].

Further, both the CS and the purified enterocin inhibited S. enterica, Sh. flexneri, Esc. coli, and V. cholerae, all of which cause serious food or waterborne gut infections such as enteric fever and diarrhea [22]. However, in the 


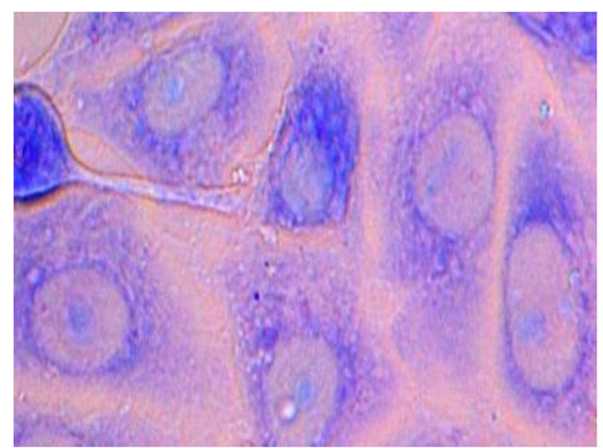

(a)

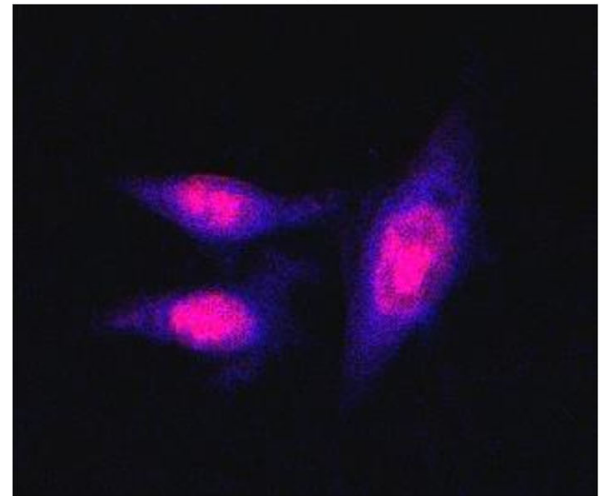

(c)

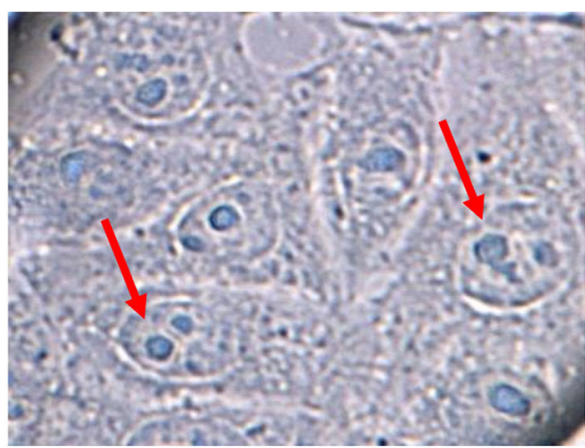

(b)

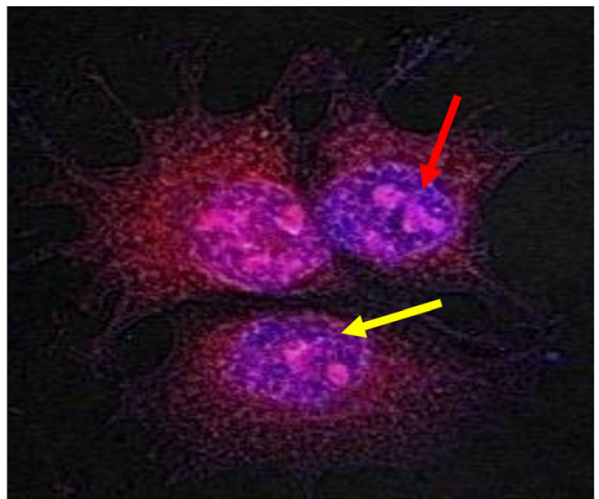

(d)

Fig. 7 Morphological changes induced in HCT-15 after $24 \mathrm{~h}$ treatment with enterocin 12a (1 $\mu \mathrm{g} / \mathrm{ml})$. (A) Giemsa-stained untreated control cells (B) Giemsa-stained enterocin-treated cells (C) PI and Hoechst 33342 co-stained untreated control cells (D) PI and Hoechst 33342 co-stained enterocin-treated cells. Yellow arrows show cell shrinkage, and red arrows show nuclear fragmentation

case of M. smegmatis, the CS but not the purified enterocin exhibited the antimicrobial activity. This indicated that non-proteinaceous substances present in the CS might be responsible for the antimicrobial activity against $M$. smegmatis. The antibiotic sensitivity profiles of the pathogenic indicator strains such as $S$. enterica (Supplementary Table 1), Esc. Coli (Supplementary Table 2), Sh. flexneri (Supplementary Table 3) and $V$. cholerae (Supplementary Table 4) used in the study revealed that all the four isolates were multi-drug resistant (MDR) pathogens as they exhibited resistance to at least one antibiotic in more than one antibiotic class [23]. Thus, considering the paucity of new antimicrobials against the MDR strains of Gram-negative pathogens [24], both E. faecium 12a and its enterocin should be further tested for their clinical efficacies in vivo infection models.

The kinetics of cumulative production of enterocin produced by E. faecium 12a in the MRS media was studied. Like other bacteriocins, enterocin 12a followed primary metabolite production kinetics [25], as it appeared in the CS in the early logarithmic phase and peaked in the late-log phase. Its concentration in the CS remained stable till $20 \mathrm{~h}$, after which it decreased by 2 -fold. The decrease in the antimicrobial activity of CS may be due to the expression of transmembrane immunity proteins that inactivate enterocin and protects the producer cells from autolysis as observed in the case of enterocin $\mathrm{P}$ [20] and cytolysin [26].

The physicochemical characterization of enterocin 12a showed that it completely lost its antimicrobial activity on treatment with all the 3 proteolytic enzymes, thereby showing its proteinaceous nature. Further, the exposure of enterocin 12a to the temperature of $100{ }^{\circ} \mathrm{C}$ for more than 15 min resulted in complete abrogation of its antimicrobial activity. As most of the heat-stable enterocins are resistant to temperatures as high as $121^{\circ} \mathrm{C}$, enterocin 12a can be considered heat-labile. Owing to its heatlabile nature and high molecular weight, enterocin 12a may be classified as class IV enterocin [27]. Enterocin 12a was also found to be resistant to $\mathrm{pH}$ ranging between 2 and 10, and all the tested organic solvents.

High molecular weight enterocins were earlier reported from various strains of $E$. faecalis viz., enterolysin A $34 \mathrm{kDa}$ [28]; bacteriocin $4164.5 \mathrm{kDa}$ [29];, EF478 45 $\mathrm{kDa}$ [30]; and anti-Candida protein $43 \mathrm{kDa}$ [31];. 
However, in the case of E. faecium, a single report showed the production of two high molecular weight bacteriocins (55 and $65 \mathrm{kDa}$ ) from the strain E. faecium ICIS $_{7}$. The enterocins of $E$. faecium $\mathrm{ICIS}_{7}$ were shown to bear no similarities with the previously reported proteins in the protein databases [32]. In this study, the characterization of enterocin $12 \mathrm{a}$ by using mass spectrometry revealed that it shared homology with $48 \%$ of 4Fe-4S domain-containing protein of E. faecalis R712. Bacterial ferredoxin i.e., $4 \mathrm{Fe}-4 \mathrm{~S}$ cluster-containing proteins are mostly acidic proteins that possess a high negative redox potential. They use iron-sulfur clusters as electron distributors in various metabolic pathways [33]. Another study reported the purification of ferredoxindomain-containing bacteriocins, pectocins M1 and M2 from Pectobacterium spp. [34]. Pectocins were shown to be natural modular proteins containing a cytotoxic domain fused to a ferredoxin-like protein that binds to the ferrichrome transporter and causes pore formation in the target cell membrane [35]. Similar natural modular bacteriocins that bind to ferrichrome transporter and cause cytolysis of target strains were also reported from Pseudomonas spp. [36]. Thus, enterocin 12a might resemble such natural modular antimicrobial proteins reported only in Gram-negative bacteria till date. $E$. faecium in particular are known to possess a high rate of gene recombination [37] that might explain the presence of such natural modular enterocin in E. faecium 12a. Furthermore, enterocin 12a appeared to be a membrane-bound protein as it was released in the CS only in the presence of Tween 80-containing MRS media or after low-frequency ultrasonication $(120 \mathrm{kHz})$ of $E$. faecium cells cultured in MRS media without Tween 80 (data not shown). A previous study has also shown that the use of Tween 80 in the broth media resulted in an 8 -fold increase in the concentration of lacticin RM in the CS [38].

Further, the mode of the antimicrobial activity of enterocin 12a was studied by flow cytometry. Results showed that the treatment of $S$. enterica cells with the purified enterocin rapidly killed the cells by altering their cell membrane permeability as evidenced by 71.7 and $91.7 \%$ increase in PI fluorescence within 15 and $30 \mathrm{~min}$, respectively. These results are similar to those reported for other bacteriocins such as nisin [39] and lacticin F [40].

Enterocin 12a inhibited the proliferation of all the tested cancer cell lines in a dose-dependent manner. Another enterocin i.e., enterocin A was earlier shown to reduce the viabilities of human cancer cell lines viz., HeLa, HT-29, AGS, and Caco- 2 selectively by $60 \%$ at the maximum dose of $120 \mu \mathrm{g} / \mathrm{ml}$ [41]. However, as compared to enterocin-A, 12a appeared to be more potent as it reduced the viabilities of all the tested cell lines in the range $64-90 \%$ at a maximum dose of $5 \mu \mathrm{g} / \mathrm{ml}$. Other purified bacteriocins such as pediocin PA-1 [42], plantaricin A [43], nisin ZP [44], and nisin [45] purified from $\mathrm{LAB}$ genera were also shown to inhibit the in vitro proliferation of human cancer cells. Nisin was shown to selectively inhibit cancer cell lines and not the normal cells [42]. Another redox bacteriocin, azurin, secreted by $P$. aeruginosa was shown to have antiproliferative effects against murine [46] and human cancer cell lines [47]. A non-toxic fragment of azurin, p28 was approved by the FDA for the treatment of malignant brain tumor, glioma [48].

Enterocin 12a was found to have negligible antiproliferative effects against human PBMCs and membranolytic effects on RBCs at the same tested doses as that of cancer cells. The selective anti-proliferative activity could be explained based on the differences between the cell membrane of cancer cells from that of normal cells. As compared to the normal cells, cancer cells are known to have increased cell membrane negative charge $[49,50]$, higher membrane fluidity [51], and the number of microvilli [52] which may result in enhanced binding of bacteriocins to the cell surface of the cancer cells. An attempt to study the mechanism of anticancer activity of enterocin $12 \mathrm{a}$ by using confocal microscopy revealed that the treatment of all the tested cancer cell lines with enterocin 12a resulted in apoptosis-like morphological changes as evident by cell shrinkage, chromatin condensation, and nuclear fragmentation [53]. Similar morphological effects on cancer cells were reported in the case of other bacteriocins such as nisin ZP [44] and azurin [54]. Cancer cells are known to possess increased amounts of negatively charged phospholipids [49, 50] on their outer cell membrane leaflet. Therefore, the anticancer effects of the enterocin 12a might be due to its cell membrane-permeabilizing effect similar to other bacteriocins [43]. However, the exact molecular mechanism of anticancer activity is under investigation.

In conclusion, these results suggest that human vaginal commensal $E$. faecium 12a secreted a novel enterocin 12a that inhibited the MDR strains of Gram-negative pathogens and also selectively inhibited the proliferation of cancer cell lines. Bacteriocin-secreting enterococci were shown to have a survival advantage in the gut, for example, bacteriocin 21-producing E. faecalis strain was able to persist for a longer time in the gut of mice by successfully replacing the indigenous enterococci including vancomycin-resistant strains, as compared to the strain that lacked the bacteriocin gene [55]. Thus, the therapeutic potential of both E. faecium $12 \mathrm{a}$ and its enterocin for the treatment of MDR strains of Gramnegative pathogens needs further investigation. Further, the study highlighted the functional property of a human vaginal commensal $E$. faecium that might play a role in protection against cervical cancer. Thus, the role of $E$. faecium 12a and its enterocin in protection against cancer in various in vivo models should also be explored. 


\section{Methods}

\section{Bacterial strains}

E. faecium 12a used for the purification of enterocin 12a was isolated from the vaginal swab sample of the healthy pre-menopausal woman and characterized in the previous study [15]. Lactobacillus spp. of fecal origin used in the study was gifted by one of the authors (Sukhraj Kaur). The LAB strains were cultured in MRS media and incubated at $37^{\circ} \mathrm{C}$ in anaerobic jars for growth. The bacterial growth media and the chemicals used in the study were mostly (except where mentioned), purchased from HiMedia Laboratories Pvt. Ltd., Mumbai, India.

The pathogenic bacterial strains used in this study were procured from Microbial Type Culture Collection (MTCC), Institute of Microbial Technology, Chandigarh, India. The indicator pathogenic bacteria such as Esc. coli MTCC 119, P. aeruginosa MTCC 741, Sh. flexneri MTCC 1457, V. cholerae MTCC 3906, S. enterica Typhimurium MTCC 733, Lis. monocytogenes MTCC 657, St. pyogenes MTCC 1927 and Staph. aureus subsp. aureus MTCC 96 were cultured in Brain Heart Infusion (BHI) broth at $37^{\circ} \mathrm{C}$ under aerobic stationary conditions. Whereas, M. smegmatis MTCC 6 was cultured in Middlebrook 7H9 broth supplemented with bovine serum albumin fraction $\mathrm{V}$ and Tween 80 under aerobic conditions at $37^{\circ} \mathrm{C}$.

\section{Agar gel diffusion assay}

The antimicrobial activities of CS and purified enterocin $12 \mathrm{a}$ were determined against various pathogenic and commensal lactobacilli strains by agar gel diffusion assay [56]. To prepare the CS, the overnight grown culture of E. faecium 12a was centrifuged (Benchtop Refrigerated centrifuge; Sigma $3 \mathrm{~K} 30$ ), at $9000 \times \mathrm{g}$ for $10 \mathrm{~min}$ at $4{ }^{\circ} \mathrm{C}$. The supernatant obtained was filter-sterilized by passing through a $0.22 \mu \mathrm{m}$ filter, and the antimicrobial activity of the CS was determined after adjusting its $\mathrm{pH}$ to 6.5.

\section{Growth curve and kinetics of production of antimicrobial substance}

To study the growth curve and kinetics of bacteriocin production by E. faecium $12 \mathrm{a}$, MRS media was inoculated with $2 \%$ overnight grown culture of E. faecium and incubated at $37^{\circ} \mathrm{C}$ in anaerobic jars. The growth of the culture was measured by reading its absorbance at $595 \mathrm{~nm}$ after every $2 \mathrm{~h}$. Simultaneously, the antimicrobial activity of the CS was determined by agar gel diffusion assay against the indicator bacteria S. enterica MTCC 733. The antimicrobial activity of CS was expressed in $\mathrm{AU} / \mathrm{ml}$, which is defined as the reciprocal of the highest dilution showing inhibition of the indicator lawn.

\section{Purification of enterocin $12 \mathrm{a}$}

Enterocin 12a was purified from the ammonium sulfate precipitates of the CS of E. faecium 12 a by cationexchange and RP-HPLC methods. For ammonium sulphate precipitation, 11 of MRS broth was inoculated with overnight grown culture (2\%) of E. faecium 12 a and incubated at $37{ }^{\circ} \mathrm{C}$ for $16 \mathrm{~h}$ in anaerobic jars. The culture was centrifuged $(9000 \times \mathrm{g})$ at $4{ }^{\circ} \mathrm{C}$ to obtain CS, and the enterocin was precipitated using $80 \%(\mathrm{w} / \mathrm{v})$ saturated ammonium sulfate with continuous stirring at $4{ }^{\circ} \mathrm{C}$ for $18 \mathrm{~h}$. Precipitated protein pellets were collected by centrifugation $(9000 \times \mathrm{g})$ and dissolved in sodium acetate buffer (20 mM; pH 4.5). The dissolved precipitates were desalted by passing through Biogel PD-10 column (GE HealthCare, USA), equilibrated and eluted with sodium acetate buffer $(20 \mathrm{mM} ; \mathrm{pH} 4.5)$. The pooled desalted fractions were loaded onto SP-Sepharose Fast Flow cation-exchange column $(50 \times 10 \mathrm{~mm}$; GE Healthcare) and eluted with a linear salt gradient of 0.1 to $1 \mathrm{M} \mathrm{NaCl}$ in sodium acetate buffer $(20 \mathrm{mM} ; \mathrm{pH} 4.5)$. The active fractions obtained from SP-Sepharose were pooled, lyophilized, resuspended in HPLC grade water, filtered $(0.2 \mu$ pore size $)$ and loaded on the $C_{18}$ HPLC column (Shimadzu Microsorb MV, 100×10 mm ID, $10 \mu \mathrm{m}$ ). Fractions were eluted with $0.01 \%$ trifluoroacetic acidcontaining solution of water and acetonitrile in the ratio $30: 70(\mathrm{v} / \mathrm{v})$. The flow rate was maintained at $3 \mathrm{ml} / \mathrm{min}$, and the eluted fractions were monitored by a photodiode array detector at $214 \mathrm{~nm}$. Fractions were collected, concentrated using rotavapour (Buchi, USA) and dissolved in MilliQ water. The antimicrobial activities and protein concentration [57] of the purified fractions were determined after each step of enterocin purification. For all the experiments HPLC fractions were concentrated, pooled and dissolved in appropriate solvent before using.

\section{Determination of molecular weight and gel overlay assay} To determine the molecular weight of the purified enterocin, denaturing polyacrylamide gel electrophoresis was carried out by using $6 \%$ stacking and $15 \%$ (w/v) separating gel [58]. The samples and the molecular weight marker (BioRad, USA) were loaded into the wells of the gel. Electrophoresis was carried out at $120 \mathrm{~V}$ and lanes of the gel were cut. One lane of the gel was stained with silver nitrate (SRL, India) and the other lane of the gel was used for the overlay assay against S. enterica [59]. For the gel overlay assay, BHI soft agar inoculated with $S$. enterica was overlaid onto the lane of the gel, incubated at $37^{\circ} \mathrm{C}$ for $24 \mathrm{~h}$, and the zone of inhibition was observed.

\section{MALDI TOF/TOF mass spectrometry (MS)}

For characterization of enterocin, silver-stained gel bands were destained, trypsinised and extracted before 
subjecting to MALDI-TOF/TOF-Proteomics Analyzer (UltrafleXtreme mass spectrometer; Bruker Daltonics Inc. Germany). Positive ion reflector mode with a mass range from 700 to $3500 \mathrm{Da}$ was used for recording the TOF spectra. For each spectrum 500 shots were accumulated. Two most abundant peptide ions were then subjected to fragmentation analysis. A combined search (MS + LIFT-MS/MS) was performed in database of protein using BioTools 3.0 software (Bruker Daltonics Inc. Germany) and MASCOT (Version 2.1, Matrix Science, London, UK), and searched against all entries in the NCBInr protein databases. The parameters used for the search were as follows: taxonomy, Firmicutes; enzyme, trypsin; the fixed modification, carbamidomethyl (C); the variable modification, Glu->pyro-Glu (N-term Q) and oxidation (M); parent ion mass tolerance at $50 \mathrm{ppm}$ and MS/MS mass tolerance of $0.7 \mathrm{Da}$; one missed cleavage allowed. The identified proteins among the top hit on the search report with individual ions scores $>44$ indicated identity or extensive homology $(p<0.05)$.

\section{Physico-chemical characterization of purified enterocin $12 \mathrm{a}$}

The physico-chemical characterization of purified enterocin $12 \mathrm{a}(1 \mu \mathrm{g} / \mathrm{ml})$ dissolved in MilliQ water was carried out. The thermostability of enterocin 12a was determined by incubating it at different temperatures for various time intervals and then determining the residual antimicrobial activity by agar gel diffusion assay. The $\mathrm{pH}$ sensitivity of enterocin was determined by setting its $\mathrm{pH}$ to values ranging from 2 to 10 and incubating at $37^{\circ} \mathrm{C}$ for $1 \mathrm{~h}$. The $\mathrm{pH}$ was again set to 6.5 before determining the residual antimicrobial activity. The stability of enterocin 12a to different solvents was determined by incubating it with various organic solvents at $50 \% \mathrm{v} / \mathrm{v}$ for $1 \mathrm{~h}$ at ambient temperature. The solvents were removed by vacuum concentration on a rotavapour before determining the residual antimicrobial activity. To study the effect of enzymes on enterocin activity, purified enterocin 12a $(1 \mu \mathrm{g} / \mathrm{ml})$ was treated with different enzymes (proteinase $\mathrm{K}$, pepsin, trypsin, and lipase; Sigma Aldrich, India) at the final concentration of $1 \mathrm{mg} / \mathrm{ml}$ for $1 \mathrm{~h}$ at $37^{\circ} \mathrm{C}$. The enzymes proteinase $\mathrm{K}$ and lipase were dissolved in $100 \mathrm{mM}$ tris-HCL buffer ( $\mathrm{pH}$ 8.0); whereas for pepsin and trypsin treatment of enterocin, the enzymes were dissolved in $1 \mathrm{mM} \mathrm{HCl}$ and enterocin was dissolved in $100 \mathrm{mM}$ tris-HCL buffer ( $\mathrm{pH}$ 8.0) and the enzyme to protein solution were mixed in the ratio 1:100. After $1 \mathrm{~h}$, enzymes trypsin, pepsin were deactivated by heating at $60{ }^{\circ} \mathrm{C}$ for $10 \mathrm{~min}$ and the enzymes proteinase $\mathrm{k}$ and lipase were inactivated at the temperature of $80^{\circ} \mathrm{C}$ for 10 min. The residual antimicrobial activity of enterocin $12 \mathrm{a}$ was then determined.

\section{Effect of enterocin 12a on the cell membrane permeability}

Cell permeabilising effects of enterocin 12a on S. enterica cells was determined by using flow cytometry with slight modifications [60]. Briefly, S. enterica cells suspended in phosphate-buffered saline (PBS; pH 7.2) at a concentration of $1 \times 10^{6}$ cells $/ \mathrm{ml}$ were treated with. Enterocin 12a $(5 \mu \mathrm{g} / \mathrm{ml})$ dissolved in MilliQ water for different time intervals. Following incubation, the cell suspensions were centrifuged, washed and suspended in PBS and thereafter stained with PI $(1.0 \mu \mathrm{g} / \mathrm{ml})$ by incubating for $15 \mathrm{~min}$ at $4{ }^{\circ} \mathrm{C}$ in the dark. The changes in the fluorescence of the cells was detected by using Flow cytometer (Accuri C6 Flow Cytometer) in the FL2 channel and the data were analyzed using $\mathrm{C}$ Flow Plus software (Becton Dickinson, San Jose, CA, USA).

Simultaneously, ten microlitres of PI-stained cell suspension were placed on glass slides in duplicates and fixed with $5 \mu$ l Flourmount solution (Sigma). The fixed cells on the glass slides were viewed under a confocal microscope (Nikon, A1R).

\section{Safety evaluation by hemolytic activity}

Hemolytic activity of enterocin 12a dissolved in phosphate- buffered saline (PBS; pH 7.2) was measured spectrophotometrically by hemoglobin release assay [61]. RBCs were isolated from the blood of healthy individuals above the age of $18 \mathrm{yrs}$. after taking their written informed consent. The protocol was approved by the Institutional Human Ethics Committee of Guru Nanak Dev University, Amritsar, and performed by following the guidelines of the Ethics Committee. Briefly, RBC cell suspension was incubated with different concentrations of enterocin $12 \mathrm{a}$ at $37^{\circ} \mathrm{C}$ for $1 \mathrm{~h}$. RBC treated with $1 \%$ Triton X-100 (Sigma Aldrich), and PBS were used as positive and negative controls, respectively. Hemoglobin release was monitored in the cell supernatant by taking absorbance at $415 \mathrm{~nm}$. The percentage $R B C$ lysis was calculated by using the equation: $\left(\mathrm{A}_{\mathrm{T}}-\mathrm{A}_{\mathrm{C}}\right) /\left(\mathrm{A}_{\mathrm{X}}-\mathrm{A}_{\mathrm{C}}\right) \times$ 10; Where $A_{T}$ is the absorbance of wells containing enterocin 12a-treated $\mathrm{RBC}, \mathrm{A}_{\mathrm{C}}$ is the absorbance of negative control well having PBS treated-RBC, and $A_{X}$ is the absorbance of positive control well containing $1 \%$ Triton X100- treated RBC.

\section{Assessment of antiproliferative activity of enterocin 12a} MTT assay was used to determine the anti-proliferative activity of enterocin 12a against human cancer cell lines such as HeLa, HCT-15, A549, MG-63, and normal human PBMCs. All the cell lines were procured from $\mathrm{Na}$ tional Centre for Cell Science, Pune, India. PBMCs were isolated from the blood of healthy individuals above the age of 18 yrs. after taking their written informed consent. The protocol was approved by the Institutional Human 
Ethics Committee of Guru Nanak Dev University, Amritsar, India, and performed by following the guidelines of the Ethics Committee. To isolate the PBMCs, densitygradient centrifugation of the blood was done by using Ficoll hypaque [62].

MTT assay was performed according to the protocol described previously $[16,63]$. Briefly, cells diluted in Dulbecco's modified Eagle's medium (DMEM) containing $10 \%$ fetal bovine serum were seeded at the concentration $4 \times 10^{5}$ cells $/ \mathrm{ml}$ in 96 -well microtitre plate and incubated for $48 \mathrm{~h}$ at $37^{\circ} \mathrm{C} ; 5 \% \mathrm{CO}_{2}$. Two-fold serial dilutions of purified enterocin 12a dissolved in filter sterlised $(0.2 \mu$ pore size) DMEM at concentrations ranging between 5.0 to $0.312 \mu \mathrm{g} / \mathrm{ml}$ were added to the wells and the plate was again incubated for $24 \mathrm{~h}$. The cells were then treated with $100 \mu \mathrm{l}$ of $0.5 \mathrm{mg} / \mathrm{ml}$ MTT (Sigma Aldrich) for $4 \mathrm{~h}$ at $37^{\circ} \mathrm{C}$. MTT-containing medium was discarded and $100 \mu \mathrm{l}$ of dimethyl sulfoxide was added to the wells to dissolve the formazan crystals. The absorbance of the wells was measured at $570 \mathrm{~nm}$ on 96-well microplate reader (Synergy $^{\text {tm }}$ HT, Bio-Tek Instruments, Inc.). The cells without enterocin were used as controls. The percentage viability of cells was assessed according to the following formula:

Percentage cell viability $=\frac{\text { Absorbance of enterocin }- \text { treated wells }}{\text { Absorbance of untreated control wells }} \times 100$

\section{Apoptosis detection by colorimetric and fluorescent staining}

Apoptosis of eukaryotic cells is characterized by morphological changes such as cell shrinkage, chromatin condensation, and nuclear fragmentation [64]. Thus, to study the effect of enterocin 12a on cell morphology, $1.2 \times 10^{6}$ HCT-15 cells were cultured on coverslips placed in 6-well tissue culture plate (Costar, USA) at $37^{\circ} \mathrm{C}$; $5 \% \mathrm{CO}_{2}$. After $24 \mathrm{~h}$, the cells were treated with $1 \mu \mathrm{g} / \mathrm{ml}$ of enterocin $12 \mathrm{a}$ and again incubated at $37^{\circ} \mathrm{C}$; $5 \% \mathrm{CO}_{2}$ for $24 \mathrm{~h}$. After that, the cells were fixed with $4 \%$ paraformaldehyde, washed with PBS (pH 7.2) and costained with Hoechst $33342(1 \mu \mathrm{g} / \mathrm{ml}$; Sigma Aldrich) and PI $(5 \mu \mathrm{g} / \mathrm{ml})$ for $15 \mathrm{~min}$. Separate sets of wells were stained with Giemsa (1:9; Merck, Darmstadt, Germany) for $20 \mathrm{~min}$. The stained cells on the coverslips were viewed under the confocal microscope (Nikon, A1R).

\section{Statistical analysis}

Data in all the experiments are representative of three experiments performed in triplicates. Data were analyzed by independent Student's $t$-test by using SPSS17.0. Significant differences of means were compared through independent Student's $t$-test by using SPSS17.0. Individual $p$ values for each data set are indicated in each figure.

\section{Supplementary Information}

The online version contains supplementary material available at https://doi. org/10.1186/s12866-021-02086-5.

Additional file 1 Supplementary Fig. 1. Silver-stained SDS-PAGE gel showing the bands of partially purified enterocin 12a obtained after SP Sepharose cation-exchange chromatography.

Additional file 2 Supplementary Fig. 2. Silver-stained SDS-PAGE gel showing a single band of purified enterocin 12a obtained after reverse phase- HPLC

Additional file $\mathbf{3}$ Supplementary Fig. 3. Agar gel overlay assay of SDSPAGE gel containing purified enterocin 12a band.

Additional file 4 Supplementary Table 1: Antibiotic susceptibility profile of S. enterica MTCC 733

Additional file $\mathbf{5}$ Supplementary Table 2. Antibiotic susceptibility profile of Esc. coli MTCC119

Additional file 6 Supplementary Table 3. Antibiotic susceptibility profile of Sh. flexneri MTCC1457

Additional file 7 Supplementary Table 4: Antibiotic susceptibility profile of $V$. cholerae MTCC 3906

\section{Abbreviations}

CS: culture supernatant; MRS: de Man Rogosa and Sharpe medium; RBCs: red blood cells; PBMC: peripheral blood mononuclear cells; PI: propidium iodide; MDR: multi-drug resistant; PBS: phosphate-buffered saline; AU/ml: arbitrary units per ml; RP-HPLC: reverse-phase high-performance liquid chromatography; U-HPLC: ultra-high-performance liquid chromatography

\section{Acknowledgements}

Dr. Preeti Sharma is thankful to the University of Potential for Excellence scheme of UGC for the fellowship. Dr. Sumanpreet Kaur is thankful to UGC for the fellowship.

\section{Authors' contributions}

SK conceived the idea and supervised the experiments. PS and SK designed the experiments and PS performed all of the experiments except MTT assay. RK and MK designed and performed the MTT assay. SPK performed cell line staining and confocal microscopic experiments. BSC designed the purification experiments. All authors discussed the results and contributed to the final manuscript. All authors read and approved the final manuscript.

\section{Funding}

This work was supported by a research grant (grant number: 42-478/2013 SR) sponsored by University Grants Commission (UGC), New Delhi, India. The funding bodies had no role in the design of the study and collection, analysis, and interpretation of data and in writing the manuscript.

\section{Availability of data and materials}

All data generated or analysed during this study are included in this published article and its supplementary information files.

\section{Ethics approval and consent to participate}

For RBCs isolation, the blood of healthy individuals above $18 \mathrm{yrs}$. of age was drawn after taking their written informed consent. The protocol was approved by the Institutional Human Ethics Committee, Guru Nanak Dev University, and performed in accordance with the guidelines of the Ethics Committee.

\section{Consent for publication}

Not applicable.

\section{Competing interests}

The authors declare no competing interests.

\section{Author details}

${ }^{1}$ Department of Microbiology, Guru Nanak Dev University, Amritsar, Punjab

143005, India. ${ }^{2}$ Department of Molecular Biology and Biochemistry, Guru 
Nanak Dev University, Amritsar, Punjab, India. ${ }^{3}$ Department of Human Genetics, Guru Nanak Dev University, Amritsar, Punjab, India.

\section{Received: 20 August 2020 Accepted: 10 January 2021 Published online: 04 February 2021}

\section{References}

1. International Agency of Research on Cancer [IARC]. World Cancer report. Geneva: World-Health-Organisation; 2018.

2. Holland T, Fowler VG Jr, Shelburne SA III. Invasive gram-positive bacterial infection in cancer patients. Clin Infect Dis. 2014;59(Suppl 5):S331-4. https:// doi.org/10.1093/cid/ciu598

3. Alibek K, Bekmurzayeva A, Mussabekova A, Sultankulov B. Using antimicrobial adjuvant therapy in cancer treatment: a review. Infect Agent Cancer. 2012;7(1):33. https://doi.org/10.1186/1750-9378-7-33.

4. Rodrigues G, Silva GG, Buccini DF, Duque HM, Dias SC, Franco OL. Bacterial proteinaceous compounds with multiple activities toward cancers and microbial infection. Front Microbiol. 2019;10. https://doi.org/10.3389/fmicb. 2019.01690

5. Cavera VL, Arthur TD, Kashtanov D, Chikindas ML. Bacteriocins and their position in the next wave of conventional antibiotics. Int J Antimicrob Agents. 2015;46(5):494-501

6. Yang SC, Lin CH, Sung CT, Fang JY. Antibacterial activities of bacteriocins: application in foods and pharmaceuticals. Front Microbiol. 2014;5:683. https://doi.org/10.3389/fmicb.2014.00241.

7. Cleveland J, Montville TJ, Nes IF, Chikindas ML. Bacteriocins: safe, natural antimicrobials for $18 \mathrm{~h}$ for food preservation. Int J Food Microbiol. 2001;71: $1-20$.

8. Mathur H, Field D, Rea MC, Cotter PD, Hill C, Ross RP. Bacteriocinantimicrobial synergy: a medical and food perspective. Front Microbiol. 2017;8:1205.

9. Hols P, Ledesma-García L, Gabant P, Mignolet J. Mobilization of microbiota commensals and their bacteriocins for therapeutics. Trends Microbiol. 2019; doi:org/https://doi.org/10.1016/j.tim.

10. Fernández L, Delgado S, Herrero H, Maldonado A, Rodríguez JM. The bacteriocin nisin, an effective agent for the treatment of Staphylococcal mastitis during lactation. J Hum Lact. 2008;24:311-6. https://doi.org/10.1177/ 0890334408317435.

11. Wu J, Hu S, Cao L. Therapeutic effect of nisin Z on subclinical mastitis in lactating cows. Antimicrob Agents Chemother. 2007;51:3131-5.

12. Joo NE, Ritchie K, Kamarajan P, Miao D, Kapila YL. Nisin, an apoptogenic bacteriocin and food preservative, attenuates HNSCC tumorigenesis via CHAC1. Cancer Med. 2012;1:295-05.

13. Kaur S, Kaur S. Bacteriocins as potential anticancer agents. Front Pharmacol. 2015;6:272.

14. Perez RH, Zendo T, Sonomoto K. Novel bacteriocins from lactic acid bacteria (LAB): various structures and applications. Microb Cell Fact. 2014;13:S3. doi. org/https://doi.org/10.1186/1475-2859-13-S1-S3.

15. Klastersky J. Management of fever in neutropenic patients with different risks of complications. Clin Infect Dis. 2004:39(Suppl 1):S32-7.

16. Sharma P, Kaur S, Kaur R, Kaur M, Kaur S. Proteinaceous secretory metabolites of probiotic human commensal Enterococcus hirae 20c, E. faecium $12 \mathrm{a}$ and L12b as antiproliferative agents against cancer cell lines. Front Microbiol. 2018;9:948.

17. Line JE, Svetoch EA, Eruslanov BV, Perelygin W, Mitsevich EV, Mitsevich IP, Levchuk VP, Svetoch OE, Seal BS, Siragusa GR, Stern NJ. Isolation and purification of enterocin E-760 with broad antimicrobial activity against gram-positive and gram-negative bacteria. Antimicrob Agents Chemother. 2008;52:1094-100

18. Liu H, Zhang L, Yi H, Han X, Gao W, Chi C, Song W, Li H, Liu C. A novel enterocin $\mathrm{T} 1$ with anti-Pseudomonas activity produced by Enterococcus faecium T1 from Chinese Tibet cheese. World J Microbiol Biotechnol. 2016; $32: 21$

19. Casaus $P$, Nilsen $T$, Cintas $L$, Nes I, Hernández $P$, Holo H. Enterocin B, a new bacteriocin from Enterococcus faecium $\mathrm{T136}$ which can act synergistically with enterocin a. Microbiology. 1997;143:2287-94.

20. Cintas LM, Casaus P, Håvarstein LS, Hernández PE, Nes IF. Biochemical and genetic characterization of enterocin $P$, a novel sec-dependent bacteriocin from Enterococcus faecium P13 with a broad antimicrobial spectrum. Appl Environ Microbiol. 1997;63:4321-30.
21. Grande Burgos MJ, Pulido RP, López Aguayo DCM, Gálvez A, Lucas R. The cyclic antibacterial peptide enterocin AS-48: isolation, mode of action, and possible food applications. Int J Mol Sci. 2014;15:22706-27.

22. Petri WA, Miller M, Binder HJ, Levine MM, Dillingham R, Guerrant RL. Enteric infections, diarrhea, and their impact on function and development. J Clin Invest. 2008;118:1277-90.

23. Magiorakos AP, Srinivasan A, Carey RB, Carmeli Y, Falagas ME, Giske CG, Harbarth S, Hindler JF, Kahlmeter G, Olsson-Liljequist B, Paterson DL. Multidrug-resistant, extensively drug-resistant and pandrug-resistant bacteria: an international expert proposal for interim standard definitions for acquired resistance. Clin Microbiol Infect. 2012;18:268-81.

24. WHO. Antibacterial agents in clinical development: an analysis of the antibacterial clinical development pipeline, including Mycobacterium tuberculosis. 2017. WHO/EMP/IAU/2017.11Geneva:WHO

25. De Vuyst L, Callewaert R, Crabbé K. Primary metabolite kinetics of bacteriocin biosynthesis by Lactobacillus amylovorus and evidence for stimulation of bacteriocin production under unfavourable growth conditions. Microbiology. 1996;142:817-27.

26. Van Tyne D, Martin MJ, Gilmore MS. Structure, function, and biology of the Enterococcus faecalis cytolysin. Toxins. 2013;5:895-911.

27. Franz CM, Van Belkum MJ, Holzapfel WH, Abriouel H, Gálvez A. Diversity of enterococcal bacteriocins and their grouping in a new classification scheme. FEMS Microbiol Rev. 2007;31:293-310.

28. Nilsen T, Nes IF, Holo $\mathrm{H}$. Enterolysin a, a cell wall-degrading bacteriocin from Enterococcus faecalis LMG 2333. Appl Environ Microbiol. 2003;69:2975-84.

29. Kurushima J, Nakane D, Nishizaka T, Tomita H. Bacteriocin protein Bacl1 of Enterococcus faecalis targets cell division loci and specifically recognizes LAla2-cross-bridged peptidoglycan. J Bacteriol. 2015;197:286-95.

30. Phumisantiphong U, Siripanichgon K, Reamtong O, Diraphat P. A novel bacteriocin from Enterococcus faecalis 478 exhibits a potent activity against vancomycin-resistant enterococci. PLoS One. 2017;12:e0186415.

31. Shekh RM, Roy U. Biochemical characterization of an anti-Candida factor produced by Enterococcus faecalis. BMC Microbiol. 2012;12:132.

32. Vasilchenko AS, Vasilchenko AV, Valyshev AV, Rogozhin EA. A novel highmolecular-mass bacteriocin produced by Enterococcus faecium: biochemical features and mode of action. Probiotics Antimicrob Proteins. 2018:1-8.

33. Lill R. Function and biogenesis of iron-Sulphur proteins. Nature. 2009;460: $831-8$.

34. Grinter R, Milner J, Walker D. Ferredoxin containing bacteriocins suggest a novel mechanism of iron uptake in Pectobacterium spp. PLoS One. 2012;7: e33033.

35. Grinter R, Josts I, Zeth K, Roszak AW, McCaughey LC, Cogdell RJ, Milner JJ, Kelly SM, Byron O, Walker D. Structure of the atypical bacteriocin pectocin M2 implies a novel mechanism of protein uptake. Mol Microbiol. 2014;93: 234-46.

36. Ghequire MG, Kemland L, Anoz-Carbonell E, Buchanan SK, De Mot R. A natural chimeric Pseudomonas bacteriocin with novel pore-forming activity parasitizes the ferrichrome transporter. MBio. 2017;8:e01961-2016.

37. de Been $M$, van Schaik W, Cheng L, Corander J, Willems RJ. Recent recombination events in the core genome are associated with adaptive evolution in Enterococcus faecium. Genome Biol Evol. 2013;5:1524-35.

38. Keren T, Yarmus M, Halevy G, Shapira R. Immunodetection of the bacteriocin lacticin RM: analysis of the influence of temperature and tween 80 on its expression and activity. Appl Environ Microbiol. 2004;70:2098-04.

39. Weeks ME, von Caron GN, James DC, Smales CM, Robinson GK. Monitoring changes in nisin susceptibility of Listeria monocytogenes Scott a as an indicator of growth phase using FACS. J Microbiol Methods. 2006;66:43-55.

40. Dalmau M, Maier E, Mulet N, Vinas M, Benz R. Bacterial membrane injuries induced by lactacin F and nisin. Int Microbiol. 2002;5:73-80.

41. Ankaiah D, Esakkiraj P, Perumal V, Ayyanna R, Venkatesan A. Probiotic characterization of Enterococcus faecium por1: cloning, over expression of Enterocin-a and evaluation of antibacterial, anticancer properties. J Funct Foods. 2017;38:280-92

42. Villarante Kl, Elegado FB, Iwatani S, Zendo T, Sonomoto K, de Guzman EE. Purification and characterization and in vitro cytotoxicity of the bacteriocin from Pediococcus acidilactici K2a2-3 against human colon adenocarcinoma (HT29) and human cervical carcinoma (HeLa) cells. World J Microbiol Biotechnol. 2011:27:975-80.

43. Sand SL, Nissen-Meyer J, Sand O, Haug TM. Plantaricin a, a cationic peptide produced by Lactobacillus plantarum, permeabilizes eukaryotic cell membranes by a mechanism dependent on negative surface charge linked 
to glycosylated membrane proteins. Biochim Biophys Acta. 1828;2013:24959.

44. Kamarajan P, Hayami T, Matte B, Liu Y, Danciu T, Ramamoorthy A, Worden F, Kapila S, Kapila Y. Nisin ZP, a bacteriocin and food preservative, inhibits head and neck cancer tumorigenesis and prolongs survival. PLoS One. 2015; 10:e0131008.

45. Joo NE, Ritchie K, Kamarajan P, Miao D, Kapila YI. Nisin, an apoptogenic bacteriocin and food preservative, attenuates HNSCC tumorigenesis via CHAC1. Cancer Med. 2012;1:295-05.

46. Yamada T, Goto M, Punj V, Zaborina O, Kimbara K, Gupta TD, Chakrabarty AM. The bacterial redox protein azurin induces apoptosis in $\mathrm{J774}$ macrophages through complex formation and stabilization of the tumor suppressor protein p53. Infect Immun. 2002;70:7054-62.

47. Yang DS, Miao XD, Ye ZM, Feng J, Xu RZ, Huang X, Ge FF. Bacterial redox protein azurin induce apoptosis in human osteosarcoma U2OS cells. Pharmacol Res. 2005;52:413-21.

48. Chakrabarty AM. Bacterial azurin in potential cancer therapy. Cell Cycle. 2016;15:1665-7.

49. Dobrzyńska I, Szachowicz-Petelska B, Figaszewski Z, Sulkowski S. Changes in electric charge and phospholipid composition in human colorectal cancer cells. Mol Cell Biochem. 2005;276:113-9.

50. Hoskin DW, Ramamoorthy A. Studies on anticancer activities of antimicrobial peptides. Biochem Biophys Acta. 2008;1778:357-75.

51. Sok M, Sentjurc M, Schara M. Membrane fluidity characteristics of human lung cancer. Cancer Lett. 1999;139:215-20.

52. Chaudhary J, Munshi M. Scanning electron microscopic analysis of breast aspirates. Cytopathology. 1995;6:162-7.

53. Leite M, Quinta-Costa M, Leite PS, Guimarães JE. Critical evaluation of techniques to detect and measure cell death-study in a model of UV radiation of the leukaemic cell line HL60. Anal Cell Pathol. 1999;19:139-51.

54. Punj V, Bhattacharyya S, Saint-Dic D, Vasu C, Cunningham EA, Graves J, Yamada T, Constantinou Al, Christov K, White B, Li G. Bacterial cupredoxin azurin as an inducer of apoptosis and regression in human breast cancer. Oncogene. 2004;23:2367-78.

55. Kommineni S, Bretl DJ, Lam V, Chakraborty R, Hayward M, Simpson P, Cao Y, Bousounis P, Kristich CJ, Salzman NH. Bacteriocin production augments niche competition by enterococci in the mammalian gastrointestinal tract. Nature. 2015;526:719-22.

56. Geis A, Singh J, Teuber M. Potential of lactic streptococci to produce bacteriocin. Appl Environ Microbiol. 1983;45:205-11.

57. Bradford MM. A rapid and sensitive method for the quantitation of microgram quantities of protein utilizing the principle of protein-dye binding. Anal Biochem. 1976;72:248-54.

58. Laemmli UK. Cleavage of structural proteins during the assembly of the head of bacteriophage T4. Nature. 1970;227:680-5.

59. Dezwaan DC, Mequio MJ, Littell JS, Allen JP, Rossbach S, Pybus V Purification and characterization of enterocin 62-6, a two-peptide bacteriocin produced by a vaginal strain of Enterococcus faecium: potential significance in bacterial vaginosis. Microb Ecol Health Dis. 2007;19:241-50.

60. Chopra L, Singh G, Jena KK, Sahoo DK. Sonorensin: a new bacteriocin with potential of an anti-biofilm agent and a food biopreservative. Sci Rep. 2015; 5:13412.

61. Paiva AD, de Oliveira MD, de Paula SO, Baracat-Pereira MC, Breukink E, Mantovani HC. Toxicity of bovicin $\mathrm{HC} 5$ against mammalian cell lines and the role of cholesterol in bacteriocin activity. Microbiology. 2012;158:2851-8.

62. Hessle C, Andersson B, Wold AE. Gram-positive bacteria are potent inducers of monocytic interleukin-12 (IL-12) while gram-negative bacteria preferentially stimulate IL-10 production. Infect Immun. 2000;68:3581-6.

63. Mosmann T. Rapid colorimetric assay for cellular growth and survival: application to proliferation and cytotoxicity assays. J Immunol Methods. 1983;65:55-63.

64. Elmore S. Apoptosis: a review of programmed cell death. Toxicol Pathol. 2007:35:495-16.

\section{Publisher's Note}

Springer Nature remains neutral with regard to jurisdictional claims in published maps and institutional affiliations.

\section{Ready to submit your research? Choose BMC and benefit from}

- fast, convenient online submission

- thorough peer review by experienced researchers in your field

- rapid publication on acceptance

- support for research data, including large and complex data types

- gold Open Access which fosters wider collaboration and increased citations

- maximum visibility for your research: over $100 \mathrm{M}$ website views per year

At BMC, research is always in progress.

Learn more biomedcentral.com/submissions 